[Freeman, S. (2005).Analysing the Early Childhood Qualification Policy Implementation: The Experience of Montessori Centres.New Zealand Annual Review of Education, 14, 195-213]

\section{Analysing the Early Childhood Qualification Policy Implementation: The Experience of Montessori Centres}

\section{SOLA FREEMAN}

\section{Abstract:}

In 2002, the Ministry of Education in New Zealand released Pathways to the Future: Nga Huarahi Arataki. This 10-year strategic plan for early childhood education was the culmination of years of advocacy, research and consultation within the early childhood sector. A key component of the plan was a staged requirement for teachers in positions of "person responsible" in early childhood centres to have a Diploma of Teaching ECE or equivalent qualification. This article analyses the impact of the first stage of the qualification requirement, using the results of a small qualitative study of six Montessori early childhood centres in Wellington, and reviews the context, literature and policy issues that inspired and drove the policy requirement. It concludes that practical difficulties for centres and their teachers to upgrade means there is a need to supervise the support, intervention and creative strategies used to ensure no one is left behind, and diversity within early childhood education in New Zealand is maintained.

$\mathrm{T}$ he New Zealand early childhood sector has been affected by numerous policy changes over the last 20 years, and one area that has been heavily contested throughout this time has been the level of qualifications needed to teach in early childhood (May, 2001). Recent research has demonstrated the importance of having qualified staff to work with young children (Podmore, Meade, \& Kerslake Hendricks, 2000; Smith et al., 2000). In response, educationalists pushed forward many policy initiatives intended to raise the early childhood education qualification base. In plans such as Education to be More (Meade, 1988), Before Five (Lange, 1988) and Future Directions (Early Childhood Education Project, 1996) thinking within the sector began to coalesce around the notion of a minimum three year teaching diploma for those working with New Zealand's youngest children. Responding to these policy recommendations (or perhaps to the implications of seesawing political ideology), successive governments since 1988 have made numerous changes to the qualification requirements. Those most affected, the practitioners, have been required to adjust to constantly moving "goal posts".

In 2002, the Labour/Progressive Coalition Government outlined its vision that all those working in teacher-led services should be fully qualified with the Diploma of Teaching ECE (DipTch ECE) or equivalent. After much consultation, the Government released its policy recommendation for this vision in the document Pathways to the Future (Ministry of Education, 2002). The new qualification requirement for early childhood centres is to be implemented in stages:

2005 (January 1) - all persons responsible to be registered teachers.

$2007-50 \%$ of all regulated staff to be fully or provisionally registered teachers

$2010-80 \%$ of all regulated staff to be fully or provisionally registered teachers

2012 - all regulated staff to be fully or provisionally registered teachers.

This policy has been attended by both critique and celebration. Some see it as a long awaited "line in the sand", raising professional requirements in the early childhood sector alongside those of the other educational sectors, and meets recent research indicators for quality practice (Bruce, 2004). Others see it as an unrealistic expectation of a sector continually struggling with low funding and a qualified teacher shortage (Thorne, 2004).

The author was involved in the development of the final report to the Minister of Education of the Early Childhood Education Strategic Plan Working Group (2001), which became Pathways to the Future (Ministry of Education, 2002) and emphasised the need to monitor the execution of the policies contained in the plan. While the early childhood sector has been very positive in accepting the direction of the plan, at the same time it has been emphasised that its implementation should have as few negative effects as possible. A policy of this magnitude imposed too hastily could leave experienced teachers without jobs, early childhood centres without teachers, and students and parents without access to the early childhood centres of their choice. 
The research project discussed later in this article sought to investigate the impact of the policy requirement for 2005 on the Montessori early childhood centres in Wellington, New Zealand. Its intention was to analyse the impact of the new qualification requirements on just one part of the diverse early childhood community, and through the results find common issues that might allow extrapolation to other areas.

\section{Literature Review}

The historical context of education policy in New Zealand over the last twenty years is a story of "political shifts" (May, 2001, p. 205). It began with a hard fought-for governmental interest in early childhood education during the late 1980s, but was followed by a dramatic swing to New Right ideology in the 1990s. In the most recent chapter, a Labour/Progressive Government has positioned itself as working collaboratively with the early childhood sector in advocating high quality early childhood education for all children in New Zealand (Dalli \& Te One, 2003). This roller coaster ride through numerous policy changes and debates in the early childhood sector has been well documented by others (Dalli, 1993; Dalli \& Te One, 2003; May, 1990a, 1990b, 1992, 1999, 2001; Meade, 1990, 1994, 1999; Meade \& Dalli, 1991; Mitchell, 1995, 1999; Wells, 1991).

A key discourse that has continued throughout the analysis concerns exactly what constitutes "quality". As May has argued, the main questions were about "quality experiences for children: what was the recipe, who was responsible, what was the cost, and how could quality be measured?" (2001, p. 232)

The governmental policy statement that tried to answer these questions was Before Five (Lange, 1988), which advocated quality provision of early childhood education (Meade \& Dalli, 1991). This 1988 policy statement articulated a strong role for government in quality assurance, and set up quality assurance mechanisms: new regulations; advisers at the Early Childhood Development Unit; monitors based with the Education Review Office; and provision of training through Colleges of Education (Meade \& Dalli, 1991).

While some of these monitoring mechanisms have remained relatively unchanged, the actual regulations and qualifications that define a "quality" trained early childhood education teacher have been greatly altered.
The policy issues surrounding the changes recommended have made this a turbulent journey for many in the early childhood sector. Teachers and centres have been in considerable confusion trying to understand and keep up with the "moving frontiers" of qualifications and/or equivalency points needed for licensing (Dalli, 1993, p. 236). This was particularly the case for Montessori teachers in New Zealand, who always seemed to miss the opportunities offered to gain equivalency to a Diploma of Teaching ECE through the various point-based or "grandparenting" pathways to qualification upgrades (Chisnall, 2002, 2003).

As a result of significant advocacy and research, the Before Five policy document identified a three year pre-service qualification as "the benchmark to which early childhood practitioners aspire as a means of achieving a high quality service" (Dalli, 1993, p. 234). In this respect, it is important to identify the disparity between kindergartens and the remaining teacher-led early childhood sector in New Zealand. Kindergartens have always had their teachers trained, and so have been able to observe the qualification issues affecting "education and care services" from the sidelines.

In 1975, the first training programme for early childcare workers was established - a one year course. With growing acceptance of international research that showed the importance of having trained staff working with children, training grew more popular - through the addition of field-based training and encouragement of centres to have at least one qualified staff member (May, 2001). This illustrates how even at the start of formalised "state" ECE training, research has been a significant contributor to the qualification policy discourse in early childhood education.

Throughout this time, the dialogue about quality in early childhood education in New Zealand has revolved around issues such as:

- the benefits of quality provision for children (Podmore et al., 2000; Smith, 1996a, 1996b; Smith et al., 2000; Wylie, 2001);

- who defines quality and the multiple perspectives of quality (Moss, 1994; Smith \& Farquhar, 1994; Farquhar, 1990 as cited in May, 2001);

- the indicators of quality (Podmore et al., 2000; Smith, 1996b; Smith et al., 2000; Wylie, 2001); and

- the evaluation of quality programmes (Education Review Office, 2000; Podmore et al., 2000) 
As identified by Smith et al. (2000) there are two parts to quality provision in early childhood education, process quality and structural quality. Process quality consists of "the general environment and the social relationships and interactions taking place in the early childhood setting which are directly experienced by children and families ... [and] involves the measurement of the actual education and care received by children" (p. 59). The structural quality components are the "easily observed and measured, and therefore regulatable aspects of quality" (p. 49). These have been identified as:

- Adult:child ratio

- Group size

- Staff education and training

- Staff wages and working conditions

- Staff stability

The one component that has been easily identified through regulatory and policy documents as a key factor in ensuring quality in early childhood education is that of qualifications (Podmore et al., 2000). Smith and Podmore and their co-authors cite significant international research in their literature reviews identifying the importance of the teacher's qualifications, and how these relate to quality educational outcomes for young children. The main New Zealand research study reviewed is the longitudinal project, Competent Children, started by Anne Meade, Cathy Wylie and Anne Kerslake Hendricks in 1993, and continued by Wylie and others who have joined her along the way. This has been a significant piece of work for many reasons. Most notably it has provided material which has highlighted the beneficial impacts of quality early childhood education right through to age 12 (Wylie, 2004). It has also identified the factors that make up quality early childhood education experiences for young children (Wylie, 1998). Amongst those key factors, the study found the highest quality early childhood education centres were those in which all staff had a Diploma of Teaching ECE and were earning at least \$15 per hour (p. 12).

Other New Zealand research cited is that carried out by Anne Smith and her colleagues, in which they studied the quality of childcare for infants and toddlers in 200 centres for under 2 year-olds. The role of the Education Review Office in defining what quality provision might (or should) look like has also been reviewed (Podmore et al., 2000). Policy initiatives such as Future Directions (Early Childhood Education Project,
1996) and Pathways to the Future (Ministry of Education, 2002) are also representative of the quality debate around qualifications.

Reviews of research from the United States by Whitebook (2003a; $2003 b)$ go even further. They find that it is the type of teacher qualification that makes the most impact on quality practice:

Specifically, classrooms where the teachers have at least a Bachelor's degree are more likely to be of higher quality - as in richer language environments, richer literacy environments, and better teacher-child interactions. Moreover, the teachers themselves are more likely to appropriately approach instruction - they are more sensitive, less punitive, and more engaged. (p. 1)

The Organisation for Economic Co-operation and Development (OECD) (2001) has also noted the trend towards longer and higher qualification levels for early childhood teachers, noting, "at least three years of tertiary education is the norm for pre-school staff in Western Europe" (p. 99).

Another area discussed in the literature on staff qualifications is the comparison between the pay and conditions which qualified teachers might expect, versus what they actually get. The impact of funding issues in relation to qualification requirements has been investigated by Farquhar (2003) and Mitchell (2001), and the issue of wages, conditions and lack of funding is significant.

In their 1997 study, Phillipsen, Burchinal, Howes, and Cryer focused on the relationship between the "iron triangle" structural quality variables (adult:child ratios, group size, and teacher education/training) and process quality variables (p. 281). Their findings indicate a strong association between the teacher's wages and classroom quality. On the other hand, Moss (1994) and Podmore et al. (2000) argue there is an acceptance that definitions of quality are based on collective values and are therefore relative. In general, there is an overriding acceptance of the structural components of quality early childhood provision - the "iron triangle" variables - and agreement that these factors cannot just be left to local interpretation. They must be defined in governmental policy - as they have been in Pathways to the Future.

\section{Policy Issues}

The issue of qualifications in early childhood has been one fraught with conflicts. At the heart is the conflict between the justifiable and commendable aim for a professionalisation of the sector, and the practical realities, such as: a lack of funds to support such an aim; a 
shortage of qualified teachers; and the complex discourse around the volunteer/professional mix in the sector (May, 2001). Over the last 20 years none of the above issues has been adequately resolved, and it would be fair to say the requirements outlined in Pathways to the Future have placed significant pressures on the sector. Exploring where those pressures are, and how they are being dealt with, now should become the focus of early childhood education policy research.

One aspect that has long been regarded as a strength of the New Zealand early childhood sector is the diversity of provision. It has been celebrated by many within New Zealand and admired from outside our shores (Meade, 1994; Meade \& Dalli, 1991). The Strategic Plan Working Group recognised this and wanted to ensure "Families and communities have equity of access to a diverse range of quality EC services that meet their needs" (Early Childhood Education Strategic Plan Working Group, 2001, p. 9). This aim has been watered down somewhat in Pathways to the Future. The intention is still there, however, expressed by an acknowledgement of the diversity of the sector as a strength $(2002$, p. 5), and a recognition of the increasing role of government in supporting the goal for quality "across the diverse ECE services" (p. 24). It would therefore be particularly disappointing if, through the implementation of such a comprehensive, celebrated and acknowledged policy document as Pathways to the Future, the impact of one strategy-striving for quality - were to defeat the goal of another - access and participation.

As already mentioned, the early childhood sector has had to meet various new requirements, and throughout the "qualification" journey the Montessori sector has remained somewhat on the outskirts (either by choice or not). However, the move to have all teachers in early childhood become qualified has meant a significant "mind shift" for many in the Montessori sector. A recent report published by the Education Review Office (ERO) has identified Montessori centres as "most at risk of not meeting the requirements" for qualified teachers at the 2005 stage of the reforms, alongside Pacifica and Steiner services (Education Review Office, 2004, p. 1).

The research project briefly outlined below was therefore timely in identifying some of the possible hurdles Montessori centres were experiencing in implementing this policy, and therefore finding themselves in the "at risk" category identified by ERO. It aims to record something of the progression in thinking-capturing both the positives and the negatives of the change.

\section{Research}

I had a number of motivations for carrying out this research project; as a parent of children in Montessori early childhood education, a Montessori teacher, early childhood education researcher, Board member of a Montessori school and member of the Strategic Plan Working Group. It was an exploratory, qualitative study, investigating the impact of the education policy for qualified teachers in Montessori early childhood centres in Wellington, via the analysis of data from semi-structured interviews. It was considered critical that the people experiencing the policy should have a large voice in evaluating it. Accordingly, the study was designed to be, following Ball's terminology, a post-modernist analysis of the localised complexities (1994, p. 14).

The use of qualitative research is particularly relevant when one is exploring the impact of policy implementation, as Rist has argued, "there is a pressing need for information on the implementation process per se." In particular there is an important role for the data to be gathered from the "day-to-day realities of bringing a new program or policy into existence. This 'ground-level' view of implementation is best done through qualitative research" (2000, p. 1008).

The five principals and owner-operators of the six Montessori early childhood centres in Wellington were interviewed in September 2004. The intention was to record the "struggle and compromise and ad hocery" that occurs within these contexts (Ball, 1994, p. 26). The interviews were informal, either at the participant's home or centre, and the discussion was framed around the following questions:

- What impacts have you experienced from the policy requirement to have all persons responsible to be qualified and registered teachers by 1 January 2005 in your Montessori centre?

- Will your centre meet the 2005 requirements? If so, how has this been achieved? If not, why not?

- Have there been any other consequences? Positive and/or negative?

- What would be the possible implications for Maori or migrant families of this policy?

\section{Results and discussion}

When the data gathered from the interviews were being analysed, five patterns from each of the six Montessori centres kept on recurring. These themes arose out of the main impacts or consequences identified by the centres in meeting the requirement for all "persons responsible" 
to have a Diploma of Teaching ECE by January 2005. It is important to see these in terms of Ball's concept of "localized complexity" (1994, p. 14), in which ad hocery and messiness surround the responses to policy, the effect, as Ball describes, of the "real struggles over the interpretation and enactment of policies" (p. 23).

This feeling certainly came through from most of the interviewees. While they all stated a commitment and belief in the general direction of the policy, most had found actually meeting the requirement in practice frustrating and exasperating.

\section{Staffing difficulties}

This seemed to be the area causing most frustration for the Principals/Managers. In particular, finding teaching staff with both the Diploma of Teaching ECE (DipTch ECE) or equivalent, and Montessori training, proved difficult:

When we have had positions to advertise we haven't had people with diplomas applying, let alone Montessori [teachers with] degrees and diplomas or whatever.

But obviously teachers that are qualified ... are few and far between and Montessori qualified teachers are even more scarce.

It is a problem, that there aren't a lot of Montessori trained teachers and I know that situation will keep getting better [but] not quick enough, not certain enough.

This shortage of qualified early childhood teachers is widely acknowledged (Meade, 2002; Thorne, 2004) and has been reflected in other situations dealing with meeting the 2005 requirement. ${ }^{1}$ Early childhood teaching is also listed on the Occupational Shortage List compiled by the New Zealand Immigration Service (2004). The consequence for these centres has been having to employ DipTch ECE teachers over Montessori qualified teachers:

But we have gone with ECE qualifications not Montessori qualifications, only because of the requirements for next year.

It's great [that we have] this ECE trained teacher but because we had to choose her over a Montessori trained teacher it does have an impact on our programme as a Montessori programme.
Impact on programme

This issue was one of significance for many centres. Three in particular noted the effect of having DipTch ECE teachers without Montessori training in their centres, and reported finding difficulties in fitting a teacher without Montessori training, coming from a different philosophical background, into a Montessori programme:

Our staff are requiring a lot of ... professional development and time to understand our philosophy, understand it is one thing, understanding and then applying, and the application I think takes time, experience and knowledge.

...to be honest I do find that there is a lot of misunderstandings because she doesn't have that Montessori background.... So although she's very well trained she certainly knows child development and things like that it's just a difference in our belief in what children are capable of, maybe.

Or as one Principal described the difficulty for teachers without Montessori training:

They get parts of it but they don't get the whole, they get the trunk and the tail but they don't know that it's an elephant and it's very difficult to convey that without training.

How the teachers with DipTch ECE and no Montessori training impact on the programme is a significant issue. It raises questions over the extent of their influence, and how involved they can be in the educational programme and planning, without Montessori training. For already diploma-qualified early childhood professionals, is this fair? There is therefore a clear expectation that they need to do additional Montessori training.

Because it impacts the programme so much when you get somebody bringing in a different philosophy without any background in the one they're coming into.

Following on from this, one centre principal did raise the concern of who defines what is qualified? Keesing-Styles has also raised this issue in relation to the policy requirement in Pathways to the Future stating "that the current definition of a quality teacher is inadequate when applied within the diverse ECE sector in New Zealand" (2003, p. 236). 
Loss of experienced teachers

Another impact on the centres is the loss of experienced Montessori teachers. All centres will lose experienced teachers at some point, either now, in order to meet the requirement, or in the future, through not being able or willing to meet the further requirements:

We will lose a lot of really talented people who have been very committed to education because of the requirement, which is a shame.

I've got the one that works with me, who's been very unwilling to take on any more training, who if she doesn't we're not going to be able to employ her really. She's currently [on] 100 points, she's currently in charge of the new entrant class in the afternoon, next year she won't be able to be.

To employ somebody else who has perhaps more relevant training or ... to work that whole day... at the moment what that would mean for us is making some existing staff redundant.

Increase in fees

For all centres, except one, there has been an increase in fees to cover the additional costs required for the centres to meet the requirementeither to attract qualified teachers, or to pay for the additional qualified teachers just to meet the requirement, or to pay the cost of up-grading current staff qualifications.

When they were asked if this has had an impact on participation levels, all centres felt it hadn't yet. Most considered that those parents who had decided to have their child in a Montessori centre accepted that there would be a cost involved.

Higher qualifications policy

Overall, all principals and managers felt extremely positive about the policy requirement. Two even acknowledged that if it hadn't been for the requirement they may not have done the additional training themselves. There was overwhelming agreement with having more qualified teachers in early childhood. It was seen as more professional, and respondents were pleased to see the government making a commitment to quality early childhood provision. All linked the qualification requirement to quality outcomes for children.

However for Montessori centres, the process has not been one of moving from unqualified to qualified teachers. Most, if not all, of their teachers already have a Montessori teaching qualification of some sort. Therefore the policy requirement has meant directing those with a (usually) one year specific Montessori qualification on to study for a broader, coherent three-year qualification. The discourse on type of qualification becomes relevant here. Research from America indicates that the more formal education teachers had, the more sensitive and appropriate caregiving they gave (Whitebook, Howes, \& Phillips, 1990). Other research cited by Whitebook went further and agreed that, "the presence of BA-level teachers with specialized training in early childhood leads to better outcomes for children" (2003b, p. 1). She goes on to argue for at least one person in charge of the class to have a four-year college degree level qualification in early childhood.

As already noted, the New Zealand research by Smith (as cited by Podmore et al., 2000) on quality provision in infant centres, and the Competent Children Project by Wylie (1998) found training, in particular a diploma level qualification, to be linked to better quality scores. Podmore and Smith and their colleagues draw the conclusion that a coherent qualification, at least a Diploma of Teachinglevel(three years), needs to be the benchmark.

All principals and managers agreed. All felt the Montessori qualification on its own was not enough to prepare an effective early childhood teacher, and did not give the broader knowledge base needed to work as a professional in the sector alongside others:

There is a breadth that comes with having different qualifications.

I like people to have more than just the basic Montessori diploma, in order, I believe, that they bring a greater ability to look at things more holistically and with a wider vision.

I see the fact that you'll have early childhood people much more trained, much more able to communicate their ideas, much more able to argue their points, and much more clearly in line with other levels of education, as a huge plus.

I think Montessori lacks in having people know different theories and all that and Montessori is a bit [of a] tunnel (uses hands to gesture a tunnel).

I think having somebody who is Montessori trained and diplomaed is ideal because I think that Montessori training in itself has not been sufficient in providing the basis for a wider aspect of early childhood education. It tends to give you the philosophy but it doesn't give you a lot of other mechanics. 
And one went even further:

I would like to see people with equivalency having to upgrade personally. Especially people who've got Montessori and not a lot else and have had it for a long time.

So how many of the centres will meet the requirement for "persons responsible" to be qualified with a DipTch ECE or equivalent by January 2005 ? Out of the six centres, five will definitely meet the requirement. One of those still needs an additional DipTch ECE teacher to cover lunch times. The centre which may not meet the requirement is hoping to employ at least one additional DipTch ECE teacher before next year. Currently three centres are on Rate 1 funding and, providing they meet this policy requirement, all will then be on Rate 2 funding. The three centres currently on Rate 1 have found the low level of funding has created additional stress, and they include the two centres having the most difficulty in meeting the requirement. They are therefore looking forward to the additional funding at Rate 2 level and the other funding promised for April 2005 (Dye, 2004). However two felt frustrated and worried about not knowing what that extra funding would be. ${ }^{2}$

The one centre that has had few (if any) difficulties in meeting this requirement has six of its seven staff with DipTch ECE or equivalent (four are registered) and three of those also have Montessori qualifications. The one staff member without the DipTch ECE has a Montessori qualification. Why has this centre got such a high percentage of qualified staff? The principal puts it down to a number of things, but mainly staff stability (the core group of teachers have been together for nearly 15 years); pay and conditions, "we pay to keep them"; good leadership, and a harmonious, team approach to working together.

This agrees strongly with the research evidence (Barnett, 2003; Phillipsen et al., 1997; Wylie, 1998) which shows a clear link between staff wages and conditions and quality outcomes for children. Staff stability is also a significant contributor to quality provision for children (Whitebook et al., 1990). It is hard to escape the conclusion that there is also a link between higher wages and better conditions (Smith et al., 2000). Centres with better qualified teachers can offer higher wages and more attractive work environments, which in turn mean lower staff turnover (Podmore et al., 2000).

\section{Conclusion}

The policy implications of the ten-year strategic plan Pathways to the Future will be, and are already, considerable for the early childhood sector of New Zealand. After so much change there is huge support for a cohesive and long term plan for the sector, and there is overwhelming acceptance of the principles and goals of the document. This small exploratory research project also indicates that there are committed people trying to make it happen.

The one centre which is struggling may need to also be creative in its response to the policy requirement, particularly for 2007. However, it is unclear whether the Ministry of Education will allow "creative" responses. But it is important that, during the process of implementation, support is available to ensure no one is left behind during the changes, and to make certain that the implementation of any one goal remains consistent with that of all the others. With this in mind, it is interesting to note that with only four weeks to the January 1, 2005 deadline, the government announced significant regulatory changes which would avoid some centres losing their licences because of the new policy requirement (Mallard, 2004). ${ }^{3}$

As Ball has argued, the execution of policy requires "commitment, understanding, capability, [and] resources" (1994, p. 19). The six centres in this study have demonstrated all of those four components in action. All centres noted the influence of resources - namely, government funding, and, in particular, the need to increase fees to cover the cost of meeting the policy requirement. At this point there has been no dramatic impact on the participation levels at these centres. However if the policy is seen alongside the other goal in Pathways to the Future, that of increasing participation and access, then as the convenor of the Strategic Plan Working Group, Anne Meade, has said herself:

If services are to remain affordable for parents as teacher salary costs go up, the Government must provide funding to support access to affordable, quality early childhood services. (Meade, 2002, para. 23)

I contend that there needs to be even more than money from the Government. There needs to be a clear acknowledgement and strong commitment from them, via the Ministry of Education, to ensure the complexities of policy implementation are not borne by the early childhood sector alone. As Ball has argued: "the translation of ... policy ... into interactive and sustainable practices ... involves productive thought, invention and adaptability" (1994, p. 19). Not only do we need 
to ensure all goals of Pathways to the Future are achieved, but we must ensure that throughout the implementation process a committed and passionate part of the diverse early childhood landscape in New Zealand - Montessori - remains a strong and valued option for parents to choose.

\section{Notes}

1. Kawhia Pre-school is to lose its license as it will be unable to meet the requirement in 2005; their licensee says they haven't found the qualified ECE teacher they need because of "the serious national shortage of early childhood teachers". Retrieved October 17,2004 from < www.scoop.co.nz>

2. Early Childhood centres are funded according to three levels of hourly funding. The minimal funding is Rate 1 , with the additional funding via Rate 2 for centres which meet higher than the licence requirements for staff:child ratios and staff diploma qualifications; the top funding Rate 3 is available to kindergartens only (Ministry of Education, 2001).

3 In December 2004, the Government announced an extension to provisional licences for centres from 3 to 12 months, in order to cover those centres unable to meet the January 2005 teacher qualification requirement.

\section{References}

Ball, S. J. (1994). Education reform: A critical and post-structural approach. Buckingham: Open University Press.

Barnett, W. S. (2003). Low wages = Low quality: Solving the real preschool teacher crisis.

Retrieved July, 2004, from <http://nieer.org/resources/policybriefs/3.pdf>

Bruce, L. (2004). NZEI supports early childhood qualification move. Retrieved January 27, 2005, from < http://www.nzei.org.nz/get/502>

Chisnall, N. (2002). On spinning, weaving and darning: Changing perspectives on Montessori in Aotearoa-New Zealand 1975-2000. Unpublished Masters thesis, Victoria University of Wellington.

Chisnall, N. (2003). Weaving the Montessori Whariki. Wellington: Institute for Early Childhood Studies.

Dalli, C. (1994). Is Cinderella back among the cinders? A review of early childhood education in the early 1990s. New Zealand Annual Review of Education, 3, 223-252
Dalli, C., \& Te One, S. (2003). Early childhood education in 2002 : Pathways to the future. New Zealand Annual Review of Education, 12, 177-202.

Dye, S. (2004, May 28). Preschool bonus to get parents working. The New Zealand Herald. Retrieved October 17, 2004, from $<$ www.nzherald.co.nz/storyprint.cfm?storyID = 35691487>

Early Childhood Education Project. (1996). Future directions: Early childhood education in New Zealand. Final report (revised edition). Wellington: New Zealand Educational Institute.

Early Childhood Education Strategic Plan Working Group. (2001). Final Report of the Strategic Plan Working Group to the Minister of Education. Wellington: Ministry of Education.

Education Review Office. (2000). What counts as quality in early childhood centres. (No. 4). Wellington: ERO.

Education Review Office. (2004). Early childhood: Readiness to implement the 2005 qualification requirements. Wellington: ERO.

Farquhar, S. E. (2003). Quality teaching early foundations. Wellington: Ministry of Education.

Keesing-Styles, L. (2003). Re-thinking the notion of qualified teachers in early childhood education. New Zealand Journal of Educational Studies, $38(2), 235-244$.

Lange, D. (1988). Before Five: Early childhood care and education in New Zealand. Wellington: Department of Education.

Mallard, T. (2004). Change to provisional licence system. Retrieved January 27, 2005, from $<$ www.beehive.govt.nz/ViewDocument.cfm?DocumentID =21684>

May, H. (1990a). From a floor to a drawer - A story of administrative upheaval. A post-Meade reflection on early childhood policy. Access, 9(2), 41-48.

May, H. (1990b). Growth and change in the early childhood services: A story of political conservatism, growth and constraint. In $\mathrm{S}$. Middleton, J. Codd, \& A. Jones (Eds.), New Zealand education policy today: Critical perspectives (pp. 94-109). Wellington: Allen \& Unwin.

May, H. (1992). After "Before Five": the politics of early childhood care and education in the nineties. Women's Studies Journal, 8(2), 83-100.

May, H. (1999). The price of partnership: the Before Five decade. In M. Thrupp (Ed.), A decade of reform in New Zealand education: Where to 
now? (pp. 18-27). Hamilton: University of Waikato, School of Education.

May, H. (2001). Politics in the playground: The world of early childhood in postwar New Zealand. Wellington: Bridget Williams Books.

Meade, A. (1988). Education to be more: Report of the Early Childhood Care and Education Working Group. Wellington: Department of Education.

Meade, A. (1990). Women and young children gain a foot in the door. Women's Studies Journal, 6(1/2), 96-110.

Meade, A. (1994, August). Before five - 5 years on. Paper presented at the special NZARE Seminar, Auckland.

Meade, A. (1994). World leaders in early childhood education. In H. McQueen (Ed.), Education is change: Twenty viewpoints (pp. 48-59). Wellington: Bridget Williams Books.

Meade, A. (1999). The early childhood landscape in New Zealand. In J. Hayden (Ed.), Landscapes in early childhood education. Cross-national perspectives on empowerment - a guide for the new millennium. (pp. 83-92). New York: Peter Lang.

Meade, A. (2002, September 19). Teacher quality vital to early education scheme. The New Zealand Herald. Retrieved October 17, 2004, from $<$ www.nzherald.co.nz/storyptrint.cfm?storyID = 28477067>

Meade, A., \& Dalli, C. (1991). Review of the early childhood sector. New Zealand Annual Review of Education, 1, 113-132.

Ministry of Education. (2001). Early childhood funding handbook. Wellington: Ministry of Education.

Ministry of Education. (2002). Pathways to the future: Nga Huarahi Arataki. Wellington: Ministry of Education.

Mitchell, L. (1996). Crossroads - early childhood education in the mid1990s. New Zealand Annual Review of Education, 5, 75-92.

Mitchell, L. (1999, June). Before five: The price of partnership. Paper presented at the Conference "A Decade of Reform in New Zealand: Where to now?", University of Waikato, Hamilton.

Mitchell, L. (2001). Bulk funding of New Zealand's early childhood services: An analysis of the impact. Wellington: New Zealand Council for Educational Research.

Moss, P. (1994). Defining quality: Values, stakeholders and processes. In P. Moss \& A. Pence (Eds.), Valuing quality in early childhood services (pp. 1-9). London: Paul Chapman.
New Zealand Immigration Service. (2004). Occupational Shortage List. Retrieved October 17, 2004, from <www.immigration.govt.nz/NR/ rdonlyres/89185A40-27D3-41F4-84BE-30129920411D/0/OSL.pdf>

Organisation for Economic Co-operation and Development. (2001). Starting strong: Early childhood education and care.

Retrieved October 16, 2004, from <www1.oecd.org/publications/ e-book/9101011E.PDF>

Phillipsen, L. C., Burchinal, M. R., Howes, C., \& Cryer, D. (1997). The prediction of process quality from structural features of child care. Early Childhood Research Quarterly, 12, 281-303.

Podmore, V. N., Meade, A., \& Kerslake Hendricks, A. (2000). Aspects of quality in early childhood education. Wellington: New Zealand Council for Educational Research.

Rist, R. C. (2000). Influencing the policy process with qualitative research. In N. K. Denzin \& Y. S. Lincoln (Eds.), Handbook of qualitative research (2nd ed.) (pp. 1001-1017). London: Sage Publications.

Smith, A. (1996a). The quality of childcare centres for infants in New Zealand. Monograph 4. Palmerston North: New Zealand Association for Research in Education.

Smith, A. (1996b). Quality programs that care and educate. Childhood Education, 72(6), 330-336.

Smith, A. B., \& Farquhar, S. E. (1994). The New Zealand experience of charter development in early childhood services. In P. Moss \& A. Pence (Eds.), Valuing quality in early childhood services (pp. 123-139). London: Paul Chapman.

Smith, A. B., Grima, G., Gaffney, M., Powell, K., Masse, L., \& Barnett, S. (2000). Strategic research initiative literature review. Early childhood education. Report to the Ministry of Education. Dunedin: Children's Issues Centre.

Thorne, S. (2004). New incentives acknowledge teacher crisis. Retrieved October 17, 2004, from

$<$ www.ecc.org.nz/mediareleases/index.php?rt $=20 \& \mathrm{rid}=487>$

Wells, C. (1991, September). The impact of change-against the odds. Paper presented at the Fifth Early Childhood Convention, Dunedin.

Whitebook, M. (2003a). Bachelor's degrees are best: Higher qualifications for pre-kindergarten teachers lead to better learning environments for children. 
Retrieved July 24, 2004, from

$<$ www.trustforearlyed.org/docs/WhitebookFinal.pdf>

Whitebook, M. (2003b). Early education quality: Higher teacher qualifications for better learning environments - A review of the literature. Retrieved July 24,2004 , from

$<$ www.iir.berkeley.edu//cscce/pdf/teacher.pdf>

Whitebook, M., Howes, C., \& Phillips, D. (1990). Who cares? Child care teachers and the quality of care in America. Executive Summary. National Child Care Staffing Study. California: Child Care Employee Project.

Wylie, C. (1998). Five years old \& competent. Wellington: New Zealand Council for Educational Research.

Wylie, C. (2001, April). Competent children: Findings and issues from the first 7 years. Paper presented at the Ministry of Social Policy Seminar, "The Long Road to Knowledge: Longitudinal Research and Social Policy", Wellington.

Wylie, C. (2004). Twelve years old \& competent. Wellington: New Zealand Council for Educational Research.

\section{The author}

Sola Freeman is mother of five-year-old twin boys and a two-year-old daughter. She is a qualified Montessori early childhood teacher with a Diploma of Teaching (Primary), and has taught in Montessori early childhood centres, most recently as Principal. She is a past-president of the Montessori Association of New Zealand and was a member of the Early Childhood Strategic Plan Working Group. Sola is currently working on her thesis for a Masters in Education, works as a tutor for the Institute for Early Childhood Studies at Victoria University of Wellington, and is Chair of a Montessori School Board of Trustees. 